\title{
Effect of $\mathrm{Sm}^{3+}$ substitution on structural and magnetic investigation of nano sized Mn-Sm-Zn ferrites
}

\author{
V Jagadeesha Angadi ${ }^{1}$, B Rudraswamy ${ }^{1 *}$, E Melagiriyappa $^{2}$, Y Shivaraj $^{3}$ and S Matteppanavar $^{1}$ \\ ${ }^{1}$ Department of Physics, Bangalore University, Bangalore 560056, India \\ ${ }^{2}$ Research Resource Center, Visvesvaraya Technological University, Belgaum 590018, India \\ ${ }^{3}$ Department of Chemistry, Government Science College, Bangalore 560001, India
}

Received: 28 May 2015 / Accepted: 20 November 2015 / Published online: 28 January 2016

\begin{abstract}
Nano size $\mathrm{Mn}_{0.4} \mathrm{Zn}_{0.6} \mathrm{Sm}_{\mathrm{x}} \mathrm{Fe}_{2-\mathrm{x}} \mathrm{O}_{4}(\mathrm{x}=0.00,0.01,0.02,0.03,0.04$, and 0.05) ferrites were prepared by solution combustion method. The structural and magnetic properties of samples were characterised by X-ray diffractometer, Fourier transform infrared spectrometer, transmission electron micrographs and magnetic properties at room temperature. The X-ray diffraction patterns and two prominent absorption bands in the frequency range $375-589 \mathrm{~cm}^{-1}$ confirmed the single phase with spinel cubic structure. The average nano crystallite sizes were in best agreements with transmission electron microscope images. Magnetic studies revealed the narrow hysteresis loops of ferrimagnetic nature at room temperature. The values of saturation magnetization $\left(M_{s}\right)$, remanence magnetization $\left(M_{r}\right)$, coercivity $\left(H_{c}\right)$, remanence ratio $\left(M_{r} / M_{s}\right)$, magneton number, anisotropy constant and Yaffet-Kittle angle decreased with the increase in $\mathrm{Sm}^{3+}$ ion concentration was attributed to relative number of ferric ions on the tetrahedral sites diminished and reduced the $\mathrm{Sm}-\mathrm{Fe}$ interaction.
\end{abstract}

Keywords: Nanoferrites; Magnetization; Anisotropy constant; Y-K angle

Pacs Nos.: 71.20.Be; 71.20.Eh; 72.80.Ga; 72.15.Eb

\section{Introduction}

In recent years, nanoferrites have attracted much attention due to their technological applications as microwave devices, high speed digital tapes and disk recording, ferrofluids, magnetic refrigeration systems, biosensors, recording colour imaging, imaging drug delivery and hyperthermia for tumor therapy $[1,2]$. The high-permeability and low-power losses at megahertz frequency can be achieved using nanocrystalline ferrites in place of micro-magnetic ferrites [3]. Mn-Zn nanoferrites have excellent properties, particularly their high initial permeability, high saturation magnetization, high resistivity and low power loss [4-7]. Nanosized $\mathrm{Mn}-\mathrm{Zn}$ ferrites are extensively used as inductors, transformers cores, rod antennas, loading coils, deflection yokes, choke coils, noise filters, recording

*Corresponding author, E-mail: brudraswamy@gmail.com heading, magnetic amplifiers and electromagnetic interference devices (EMI) etc. Moreover, these ferrites are very important in biomedicine as magnetic carriers for bioseperation, enzymes and proteins immobilization, magnetic resonance imaging (MRI), sensing as well as therapeutic applications such as ac and ac magnetic fieldassisted cancer therapy [8-10]. The most significant properties in the nano-region depend on the shape, size, crystallinity and occupation of the nano-particle [11].

The rare earth substituted ferrites are nowadays under extensive investigations and are becoming promising materials for various applications. Studies on rare earth ferrites have shown that they are more effective for the relief of acute and chronic pain or discomfort due to the various injuries and ailments [12]. It is well known that the rare earth ions have unpaired $4 f$ electrons screened by $5 s$ and $5 p$ orbital and are almost not affected by the potential field of surroundings ions. The substitution of rare earth ions into spinel ferrites results in occurring of $4 f-$ $3 d$ couplings which determine the magneto crystalline 
anisotropy in ferrites and can also improve the electrical and magnetic properties of spinel ferrites [13].

Nanosized $\mathrm{Mn}-\mathrm{Zn}$ ferrites are synthesized by several methods, such as solid state reaction [14], chemical coprecipitation [15], hydrothermal synthesis [16, 17], solgel combustion [18, 19], spray pyrolysis methods [20], citrate precursor [21] etc. However, most of these methods are economically unfeasible for large scale production of ferrites. Therefore, in the present investigation, the combustion reaction synthesis has been used successfully to obtain nanosized particles. This method has several advantages due to its simplicity, short reaction time and inexpensive nature, allowing for the production of fine, homogeneous crystalline powders without the risk of contamination, lower consumption of energy and elimination of intermediary calcinations stages during synthesis [22]. In the present investigation, the effect of $\mathrm{Sm}^{3+}$ ions on structural and magnetic properties of $\mathrm{Mn}-\mathrm{Zn}$ nanoferrites prepared by combustion method is reported.

\section{Experimental details}

In the present study the polycrystalline $\mathrm{Mn}_{0.4}^{2+} \mathrm{Zn}_{0.6}^{2+} \mathrm{Sm}_{\mathrm{x}}^{3+} \mathrm{Fe}_{2-\mathrm{x}}^{3+} \mathrm{O}_{4}$ were prepared by solution combustion route, using stiochiometric molar amounts of manganese nitrate $\left[\mathrm{Mn}\left(\mathrm{NO}_{3}\right)_{2} \cdot 4 \mathrm{H}_{2} \mathrm{O}\right]$, zinc nitrate $\left[\mathrm{Zn}\left(\mathrm{NO}_{3}\right)_{2} \cdot 6 \mathrm{H}_{2} \mathrm{O}\right]$, and iron nitrate $\left[\mathrm{Fe}\left(\mathrm{NO}_{3}\right)_{3} \cdot 9 \mathrm{H}_{2} \mathrm{O}\right]$, samarium nitrate $\left[\mathrm{Sm}\left(\mathrm{NO}_{3}\right)_{2}\right]$ as oxidizer and mixture of urea $\left[\mathrm{NH}_{2} \mathrm{CONH}_{2}\right]$ and glucose $\left.\left[\mathrm{C}_{6} \mathrm{H}_{12} \mathrm{O}_{6}\right)\right]$ as fuels. The stiochiometric compositions of metal nitrates and fuels were evaluated based on the total oxidizing and reducing valences of the component. The oxidizer to fuel ratio was taken as 1: (60:40). All the metal nitrates and fuels were diluted with $30 \mathrm{ml}$ double distilled water and thoroughly mixed using magnetic stirrer with the speed of $800 \mathrm{rpm}$ for $1 \mathrm{~h}$ until the reactants were dissolved completely to get homogenous solution. This homogeneous solution containing redox mixture was taken in a Pyrex dish and kept in a pre heated muffle furnace maintained at $450 \pm 10{ }^{\circ} \mathrm{C}$. Initially, the solution boiled, then frothed and ignited to yield fine powder of $\mathrm{Sm}^{3+}$ co-substituted $\mathrm{Mn}-\mathrm{Zn}$ rapidly because these were exothermic. The whole combustion process was complete in $<20 \mathrm{~min}$, whereas the reaction time of the actual ignition was $<5 \mathrm{~s}$. The samples were pressed into pellets by applying the pressure of $5-$ ton $/ \mathrm{cm}^{2}$ for $5 \mathrm{~min}$. The pellets were sintered at $1000{ }^{\circ} \mathrm{C}$ for $8 \mathrm{~h}$ and furnace cooled to room temperature. The X-ray diffraction (XRD) patterns were obtained at room temperature on Philips make PW-3710 X-ray powder diffractometer in the range of 20-80 with $C u K_{\alpha}$ radiation $(\lambda=0.154056 \mathrm{~nm})$. The crystallite size was calculated by Debye-Scherrer method, given by Eq. (1) below. The IR absorption spectra of powdered samples were recorded in the range of 350$800 \mathrm{~cm}^{-1}$ on Perkin-Elmer FT-IR spectrum one spectrometer using $\mathrm{KBr}$ pellet technique. The distance between magnetic ions and hopping lengths in octahedral sites and tetrahedral sites were calculated by using Eq. (2) [23]

$D_{P}=\frac{0.94 \lambda}{\beta \times \cos \theta}$

$L_{A}=a \frac{\sqrt{3}}{4} \quad$ and $\quad L_{B}=a \frac{\sqrt{3}}{2}$

The magnetization measurement was carried out in vibrating sample magnetometer (VSM) mounted on an electromagnet with a bipolar source of maximum applied field of $1.5 \mathrm{~T}$ at room temperature. The Remanence ratio $(S)$, Magneton number $\left(\eta_{B}\right)$, Anisotropy constant $(K)$, and $\mathrm{Y}-\mathrm{K}$ angle of the samples with different $\mathrm{Sm}^{3+}$ concentration is calculated using Eqs. (3)-(6) [24, 25].

$R=\frac{M_{r}}{M_{s}}$

$\left(\eta_{B}\right)=\frac{M W \times M s}{5585}$

$K=\frac{H c \times M s}{0.96}$

$\operatorname{Cos} \alpha_{Y-k}=\frac{\eta_{\mathrm{B}}+5(1-X)}{5(1+X)}$

\section{Results and discussion}

Figure 1 shows the XRD pattern of as-prepared $\mathrm{Mn}_{0.4} \mathrm{Zn}_{0.6} \mathrm{Sm}_{\mathrm{x}} \mathrm{Fe}_{2-\mathrm{x}} \mathrm{O}_{4} \quad(\mathrm{x}=0.00, \quad 0.01, \quad 0.03, \quad 0.05)$

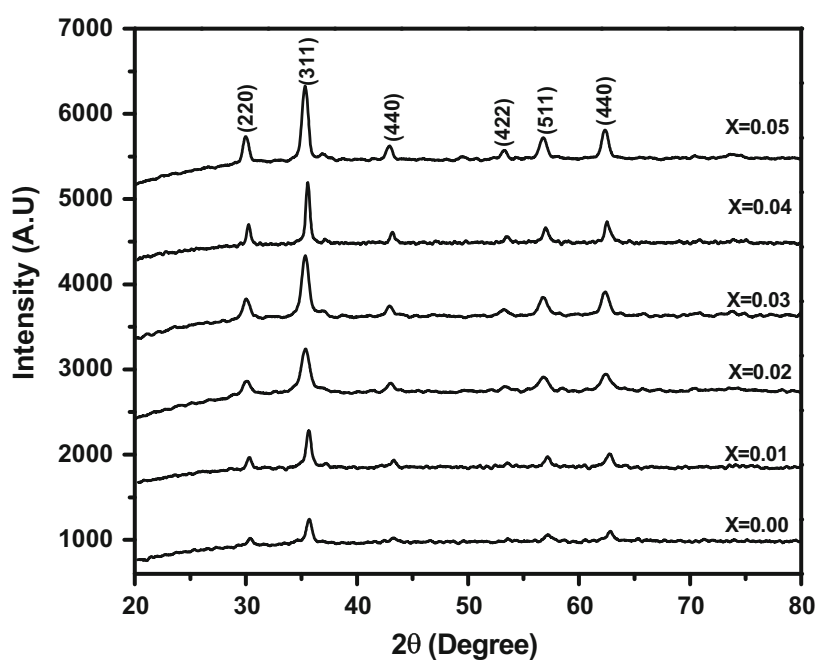

Fig. 1 XRD patterns of as-synthesized $\mathrm{Mn}_{0.4} \mathrm{Zn}_{0.6} \mathrm{Sm}_{\mathrm{x}} \mathrm{Fe}_{2-\mathrm{x}} \mathrm{O}_{4}$ $(\mathrm{x}=0.00,0.01,0.02,0.03,0.04$ and 0.05$)$ 
Table 1 Data on lattice parameter $(A)$, crystallite size $\left(\mathrm{D}_{\mathrm{p}}\right)$ by XRD, particle size $(\mathrm{T})$ by TEM, hopping length $\left(\mathrm{L}_{\mathrm{A}}\right.$ and $\left.\mathrm{L}_{\mathrm{B}}\right)$ and position of absorption bands of $\mathrm{Mn}_{0.4} \mathrm{Zn}_{0.6} \mathrm{Sm}_{\mathrm{x}} \mathrm{Fe}_{2-\mathrm{x}} \mathrm{O}_{4}$ (x = 0.00, 0.01, 0.02, 0.03, 0.04, and 0.05)

\begin{tabular}{|c|c|c|c|c|c|c|c|}
\hline \multirow{2}{*}{$\begin{array}{l}\text { Composition } \\
(\mathrm{X})\end{array}$} & \multirow{2}{*}{$\begin{array}{l}\text { Lattice parameter } \\
\text { (a) } \AA\end{array}$} & \multirow{2}{*}{$\begin{array}{l}\text { Particle size (XRD) } \\
\text { nm }\end{array}$} & \multirow{2}{*}{$\begin{array}{l}\text { Particle size (TEM) } \\
\text { nm }\end{array}$} & \multicolumn{2}{|c|}{ Hoping lengths } & \multicolumn{2}{|c|}{ Absorption bands } \\
\hline & & & & $\begin{array}{l}\text { A- site } \\
\left(\mathrm{L}_{\mathrm{A}}\right)\end{array}$ & $\begin{array}{l}\text { B-site } \\
\left(\mathrm{L}_{\mathrm{B}}\right)\end{array}$ & $\begin{array}{l}v_{1} \\
\left(\mathrm{~cm}^{-1}\right)\end{array}$ & $\begin{array}{l}v_{2} \\
\left(\mathrm{~cm}^{-1}\right)\end{array}$ \\
\hline 0.00 & 8.344 & 27 & 30 & 3.613 & 7.226 & 529 & 343 \\
\hline 0.01 & 8.410 & 16 & 18 & 3.641 & 7.283 & 537 & 380 \\
\hline 0.03 & 8.412 & 13 & 14 & 3.642 & 7.285 & 537 & 358 \\
\hline 0.05 & 8.417 & 10 & 12 & 3.644 & 7.289 & 537 & 372 \\
\hline
\end{tabular}

nanostructured particles from which proper phase identification cannot be observed. Analysis of XRD pattern confirms the presence of strong diffraction peaks corresponding to the planes (1 111$),\left(\begin{array}{lll}2 & 2 & 0\end{array}\right),\left(\begin{array}{lll}3 & 1 & 1\end{array}\right),\left(\begin{array}{lll}4 & 0 & 0\end{array}\right)$, (4 2 2), ( $\left.\begin{array}{llll}5 & 1 & 1 / 3 & 3\end{array}\right),(440)$, indicating the formation of spinel cubic structure. After certain limit, Sm accumulates at the grain boundaries of $\mathrm{Mn}-\mathrm{Zn}$ Ferrite and forms orthorhombic phase. This may be due to the presence of $\mathrm{SmFe}_{2} \mathrm{O}_{3}$ phase formed due to high reactivity of iron with samarium [26]. The lattice constant (Table 1) is found to increase with increase in $\mathrm{Sm}^{3+}$ ion concentration which is attributed to the fact that the ionic radii of $\mathrm{Fe}^{3+}(0.67 \AA)$ is smaller than that of $\mathrm{Sm}^{3+}(0.99 \AA)$ ions substituted for $\mathrm{Sm}^{3+}$ ions. This confirms the occupancy of samarium on octahedral site [26]. The particles size of the powder samples estimated from the full width at half maxima of pattern (FWHM) of their (311) XRD planes by employing Debye-Scherrer relation [27]. The average paricle size of the samples is in the range of $10-27 \mathrm{~nm}$.

Infrared spectra of the samples for different compositions are shown in Fig. 2. Infrared spectra of the samples show two prominent absorption bands, $v_{1}$ near $600 \mathrm{~cm}^{-1}$ attributed to tetrahedral complexes and $v_{2}$ around $400 \mathrm{~cm}^{-1}$ assigned to octahedral complexes. The positions of the absorption bands are listed in Table 1. The difference in frequencies between $v_{1}$ and $v_{2}$ is due to changes in bond length $\left(\mathrm{Fe}^{3+}-\mathrm{O}^{2-}\right)$ at tetrahedral and octahedral sites [28]. The slight change in band position, particularly in $v_{1}$ and $v_{2}$ suggests that the method of preparation, grain size and porosity can influence in locating the band position [29]. It can be seen that the absorption band $v_{1}$ does not show any splitting or shoulders and hence the possibility of $\mathrm{Fe}^{2+}$ ions at A-sites is ruled out [30]. On substitution of $\mathrm{Sm}^{3+}$ ion content, $v_{1}$ continues to be widen is attributed to atomic mass and volume of the dopant, which affects $\mathrm{Fe}-\mathrm{O}$ distances on octahedral sites, suggesting that $\mathrm{Sm}^{3+}$ ions occupy octahedral lattice sites [31]. The shift occurs in absorption bands $v_{1}$ and $v_{2}$ for each octahedral and tetrahedral site due to the perturbation occurring in the $\mathrm{Fe}^{3+}-$ $\mathrm{O}^{2-}$ bond by introducing $\mathrm{Sm}^{3+}$ ions [31].

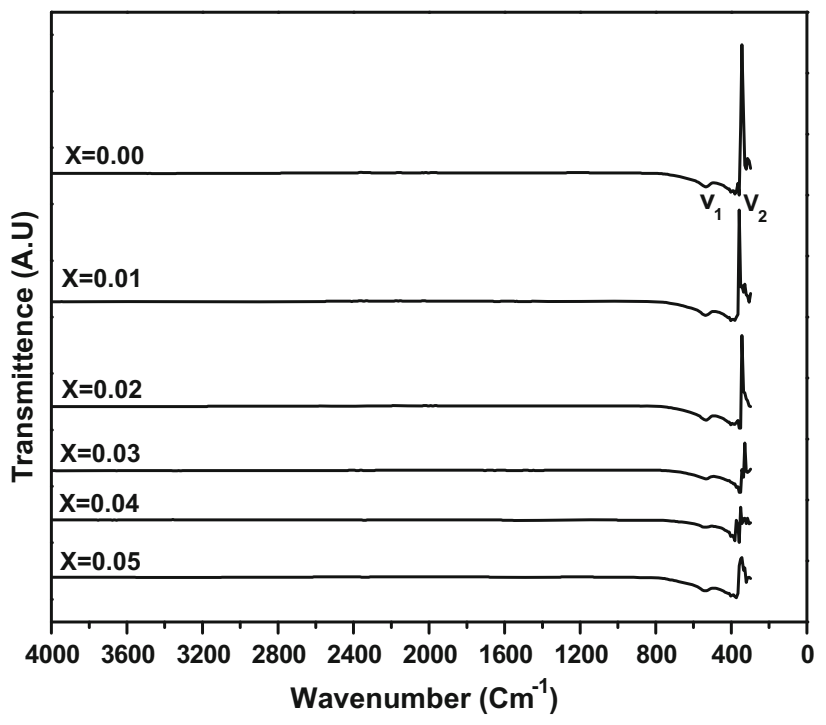

Fig. 2 FTIR spectra of as-synthesized $\mathrm{Mn}_{0.4} \mathrm{Zn}_{0.6} \mathrm{Sm}_{\mathrm{x}} \mathrm{Fe}_{2-\mathrm{x}} \mathrm{O}_{4}$ $(\mathrm{x}=0.00,0.01,0.02,0.03,0.04$, and 0.05$)$

The TEM micrographs of samples with $\mathrm{Sm}^{3+}$ content $(\mathrm{x}=0.03$ and 0.05$)$ annealed at $350^{\circ} \mathrm{C}$ are shown in Fig. 3. It is clear that the particles are spherical in shape and are agglomerated. This agglomeration can be attributed to magnetic interaction arising among ferrite nano-particles. The particle size $\left(\mathrm{D}_{\mathrm{T}}\right)$ calculated from TEM, is larger than crystal size estimated by XRD, indicating that majority of particles in samples are multi-crystal particles. The addition of $\mathrm{Sm}^{3+}$ ions reduces the grain growth probably due to deposition of $\mathrm{Sm}^{3+}$ on the grain boundaries which in turn hampers its motion [32].

Figure 4 shows the magnetic hysteresis curves for different compositions of the samples at room temperature very narrow hysteresis loops, reveal the behaviour of soft magnetic material. From the Table 2, it is clear that the values of saturation magnetization $\left(M_{S}\right)$, remanence magnetization $\left(M_{r}\right)$, remanence ratio $\left(M_{r} / M_{s}\right)$, and coercivity $\left(H_{c}\right)$ and magneton number $\left(n_{B}\right)$ decrease with increase in $\mathrm{Sm}^{3+}$ ion concentration. According to Neel's two sub-lattice model of ferrimagnetism, the net moment is given by the formula $\mu_{B}=M_{B}(x)-M_{A}(x)$, where $M_{A}$ and $M_{B}$ are 

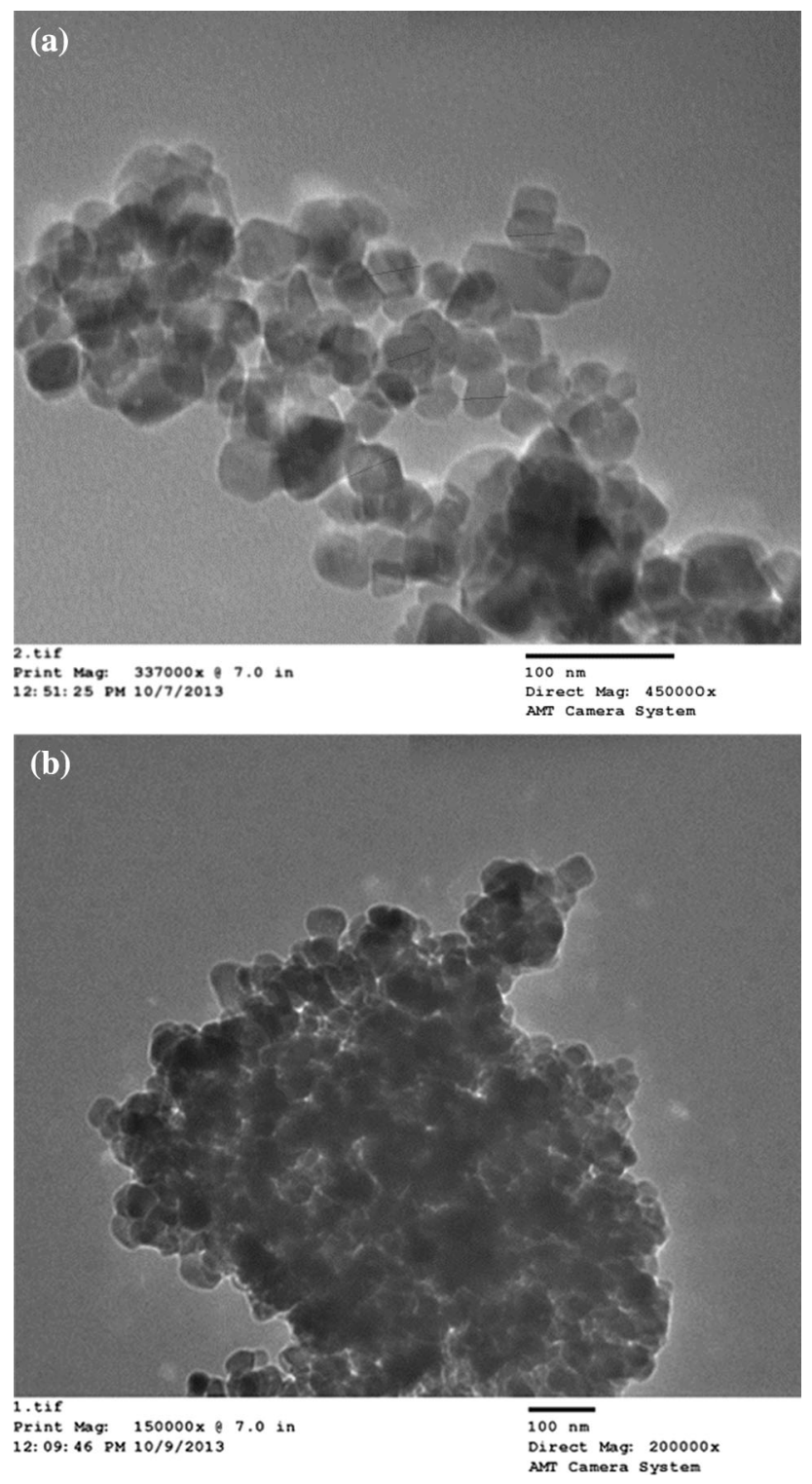

Fig. 3 TEM images of as-synthesized (a) $\mathrm{Mn}_{0.4} \mathrm{Zn}_{0.6} \mathrm{Sm}_{0.03} \mathrm{Fe}_{1.97} \mathrm{O}_{4}$ and (b) $\mathrm{Mn}_{0.4} \mathrm{Zn}_{0.6} \mathrm{Sm}_{0.05} \mathrm{Fe}_{1.95} \mathrm{O}_{4}$

the A and B sub-lattice magnetic moments in $\mu_{B}$ [33]. The existence of random canting of particle surface spins, surface effects and the occurrence of a glassy state have been reported to play an active role in the decline of magnetization values [34]. The magnetic moment decreases significantly in $\mathrm{Sm}^{3+}$ substituted samples which is attributed to small free ion of magnetic moment of $\mathrm{Sm}^{3+}$, $n_{B}=1.58 \mu_{B}$ [35] as against for $\mathrm{Fe}^{3+} ; n_{B}=5 \mu_{B}$ at room temperature [36, 37]. The substituted $\mathrm{Sm}^{3+}$ ion with $4 f$ and $5 p$ electrons, occupies on octahedral site and hence $\mathrm{Sm}-\mathrm{Fe}$ interaction is weaker than $\mathrm{Fe}-\mathrm{Fe}$ interaction. This dilutes the interaction in octahedral site and decreases the Curie temperature.

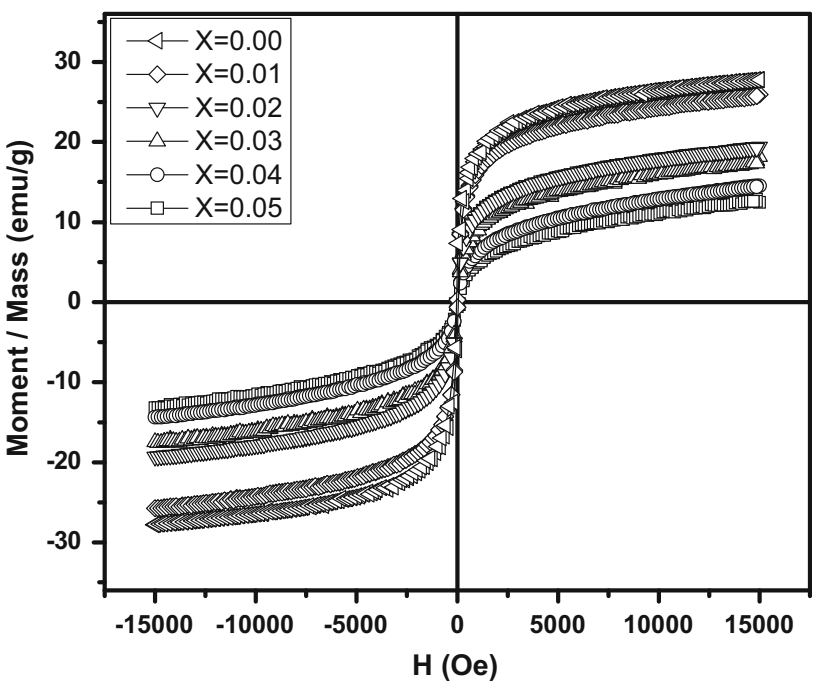

Fig. 4 Hysteresis loop of as-synthesized $\mathrm{Mn}_{0.4} \mathrm{Zn}_{0.6} \mathrm{Sm}_{\mathrm{x}} \mathrm{Fe}_{2-\mathrm{x}} \mathrm{O}_{4}$ $(\mathrm{x}=0.00,0.01,0.02,0.03,0.04$, and 0.05$)$

In ferrites, the coercive force is obtained by reversal of the directions of the wall movement and that of domain rotation on reversing the direction of the applied magnetic field. Generally, the effective pinning for domain wall causes the coercivity; it is known that the larger grain size decreases $H_{C}$ [38]. In the present investigation, the coercive values are low; hence probability of domain rotation is also lower. The materials with larger grain size have been used to achieve lower core loss [38].

In the present work, the $\mathrm{Y}-\mathrm{K}$ angles decrease with the increase in $\mathrm{Sm}^{3+}$ ion concentration. The decrease in the $\mathrm{Y}-$ $\mathrm{K}$ angles suggests a decrease of triangular spin arrangements on $\mathrm{B}$ sites to produce the increment in A-B interaction. The effect of B-B interaction can be masked by strong A-B interaction to cause the spin on B sites to be aligned parallel to each other. However, the substitution of $\mathrm{Sm}^{3+}$ seems to lead to canted type of arrangements on $\mathrm{B}$ sites to enhance the A-B interactions. Therefore, $\mathrm{Sm}^{3+}$ substitution brings changes in magnetization, which can be attributed to the presence of $\mathrm{Y}-\mathrm{K}$ angles in the spin system on $\mathrm{B}$ sites. The condition for $\mathrm{Y}-\mathrm{K}$ angles has been discussed from the consideration of the molecular field approximation using a noncolinear three sub-lattice model $[39,40]$.

\section{Conclusions}

Samarium substituted MnZn nanoferrites have been prepared by combustion method. XRD analysis reveals that all the prepared samples are single phase cubic spinel without any secondary phase. Increase in lattice constant value with samarium doping indicates the expansion of unit cell. The 
Table 2 Data on saturation magnetization $\left(\mathrm{M}_{\mathrm{S}}\right)$, remanence magnetization $\left(\mathrm{M}_{\mathrm{r}}\right)$, remanence ratio $\left(\mathrm{M}_{\mathrm{r}} / \mathrm{M}_{\mathrm{s}}\right)$, and coercivity $\left(\mathrm{H}_{\mathrm{c}}\right)$, magneton number $\left(\mathrm{n}_{\mathrm{B}}\right)$, anisotropy constant $(\mathrm{k})$ and $\mathrm{Y}-\mathrm{K}$ angle of of $\mathrm{Mn}_{0.4} \mathrm{Zn}_{0.6} \mathrm{Sm}_{\mathrm{x}} \mathrm{Fe}_{2-\mathrm{x}} \mathrm{O}_{4}(\mathrm{x}=0.00,0.01,0.02,0.03,0.04$, and 0.05)

\begin{tabular}{llllllll}
\hline $\begin{array}{l}\text { Samarium } \\
\text { concentration } \\
(\mathrm{X})\end{array}$ & $\begin{array}{l}\text { Saturation } \\
\text { Magnetization }\left(M_{\mathrm{S}}\right) \text { in } \\
\text { emu/gm }\end{array}$ & $\begin{array}{l}\text { Remenant } \\
\text { magnetization }\left(M_{\mathrm{r}}\right) \text { in } \\
\text { emu/gm }\end{array}$ & $\begin{array}{l}\text { Coercivity } \\
\left(H_{\mathrm{c}}\right) \text { in Oe }\end{array}$ & $\begin{array}{l}\text { Remanance } \\
\text { ratio } M_{\mathrm{r}} / M_{\mathrm{s}}\end{array}$ & $\begin{array}{l}\text { Magneton } \\
\text { number }\left(n_{\mathrm{B}}\right) \\
\mu_{\mathrm{B}}\end{array}$ & $\begin{array}{l}\text { Anisotropy } \\
\text { constant }(\mathrm{K}) \text { in } \\
\text { erg/Oe }\end{array}$ & $\begin{array}{l}\text { Yafet-Kittle } \\
\text { angle } \alpha_{\mathrm{Y}-\mathrm{K}}\end{array}$ \\
\hline 0.00 & 27.77 & 16.68 & 50.14 & 0.7148 & 1.703 & 1450 \\
0.01 & 25.92 & 18.53 & 38.93 & 0.6491 & 1.589 & 1051 & 1.340 \\
0.02 & 19.40 & 12.60 & 16.47 & 0.6006 & 1.189 & 333 & 208 \\
0.03 & 18.13 & 10.82 & 11.01 & 0.5968 & 1.111 & 1.320 \\
0.04 & 14.53 & 07.23 & 09.31 & 0.4975 & 0.891 & 69 & 1.242 \\
0.05 & 12.85 & 05.81 & 04.10 & 0.4521 & 0.788 & 6 \\
\hline
\end{tabular}

absorption bands in FTIR are found in the expected range of spinel ferrites. TEM images show the samples are spherical in shape and agglomerated. The magnetic behavior of pure and samarium doped magnesium ferrite particles shows soft ferrimagnetic nature. The decrease in saturation magnetization and remnant magnetization is attributed to the weak magnetic interactions.

Acknowledgments V. Jagadeesha Angadi and B. Rudraswamy are thankful to the UGC, New Delhi for giving financial support through the Major Research project.

\section{References}

[1] P A Shaikha, R C Kambalea, A V Raoa and Y D Kolekar $J$. Alloys Compd. 492590 (2010)

[2] X Cao, G Liu, Y Wang, J Li and R Hong J. Alloys Compd. 497 L9 (2010)

[3] K Praveena, K Sadhana, S Bharadwaj and S R Murthy J. Magn. Magn. Mater. 3212433 (2009)

[4] H B Yang et al. J. Magn. Magn. Mater. 322173 (2010)

[5] A C F M Costa, V J Silva, C C Xin, D A Vieira, D R Cornejo and R H G A Kiminami J. Alloys Compd. 495503 (2010)

[6] M M Hessien, M M Rashad, K El-Barawy, I A Ibrahim J. Magn. Magn. Mater. 3201615 (2008)

[7] A Goldman Modern Ferrite Technology, 2nd edn. (Berlin: Springer) (2006)

[8] P Papazoglou, F Eleftheriou and V T Zaspalis J. Magn. Magn. Mater. 29625 (2006)

[9] J Wang, T Deng and Y Dai J. Alloys Compd. 419155 (2006)

[10] S F Mansour and M A Elkestawy Ceram. Int. 371175 (2011)

[11] S D Shenoy, P A Joy and M R Anantharaman J. Magn. Magn. Mater. 269217 (2004)

[12] E Ateia, Egypt J. Sol. 29(2) 317 (2006)

[13] S Jie, W Lixi, X Naicen and Z Qitu J. Rare Earth 28451 (2010)

[14] M R Meshram, N K Agrawal, B Sinha and P S Misra J. Magn. Magn. Mater. 271214 (2004)

[15] R Arulmurugan, G Vaidyanathan, S Sendhilnathan and B Jeyadevan J. Magn. Magn. Mater. 29883 (2006)
[16] J F Wang, C B Ponton and I R Harris, J. Magn. Magn. Mater. 298122 (2006)

[17] J F Wang, C B Ponton and I R Harris J. Alloys Compd. 403104 (2005)

[18] A Mali and A Ataie J. Alloys Compd. 399245 (2005)

[19] Q Fang, H Cheng, K Huang, J Wang, R Li and Y Jiao J. Magn. Magn. Mater. 294281 (2005)

[20] C H Chen, M H J Emond, E M Kelder, B Meester and J Schoonman J. Aerosol Sci. 30(7) 959 (1999)

[21] A Thakur and M Singh Ceram. Inter. 29505 (2003)

[22] A C F M Costa, V J Silva, D R Cornejo and L G F Vieira $J$. Magn. Magn. Mater. 320 e370 (2008)

[23] E Ateia Egypt. J. Solids 29(2) 329 (2006)

[24] A A Pandit, A R Shitre, D R Shengule and K M Jadhav, J. Mater. Sci. 40423 (2005)

[25] M L Mane et al, J. Mol. Struct. 103527 (2013)

[26] E Melagiriyappa, M Veena, A Somashekarappa, G J Shankaramurthy and H S Jayanna Indian J. Phys. 88795 (2014)

[27] H P Klug and L E Alexander, X-ray Diffraction Procedure. (Wiley-Inter Science, New York) Ch. 9 (1984)

[28] O M Hemeda J. Magn. Magn. Mater. 28136 (2004)

[29] M A El Hiti, A I El Shora, A S Seoud and S M Hammed Phase Trans. 5635 (1995)

[30] V A Halfner, N D Zverev, V P Romanov Phys. Status Solidi A 12623 (1975)

[31] E Melagiriyappa, H S Jayanna J. Alloys Compd. 482147 (2009)

[32] A B Gadkari, T J Shinde and P N Vasambekar Mater. Charact. 60(11) 1328 (2009)

[33] L Neel Proc. Phys. Soc. Lond. A-65 869 (1952)

[34] J Chand, S Verma, M Singh J. Alloys Compd. 552264 (2013)

[35] B N Figgis, in: G Wilkinson, Gillard and J A Mc Cleverty (eds.), Comprehensive Coordination Chemistry, (New York: Pergamon) p 261 (1987)

[36] K J Standley Oxide Magnetic Materials (Oxford: Clarendon Press) p 52 (1972)

[37] V Naidu, S Vijayaragavan, R Legadevi and A Santhil Kumar Int. J. Comp. Appl. 307 (2011)

[38] P Yaseneva, M Bowker and G Hutchings Phys. Chem. Chem. Phys. 1318609 (2011)

[39] M U Rana, M Ul-Islam, I Ahmad and T Abbas J. Magn. Magn. Mater. 187242 (1999)

[40] N S S Murthy, M G Natera, S I Youssef, R J Begum Phys. Rev. 181969 (1969) 